\title{
Ethnopharmacological use of wild vegetable plants belonging to the Polygonaceae Juss. family spread in the Azerbaijan flora
}

\author{
Sayyara C. Ibadullayeva', Gulnara Sh. Shiraliyeva', Lala Z. Gurbanova², Aytekin A. Askerova², Asmer E. \\ Huseynova ${ }^{3}$, Lamiya M. Seyidova' \& Hilal Z. Qasimov ${ }^{4}$
}

${ }^{1}$ Department of Ethnobotany, Institute of Botany of ANAS, AZ1004, Badamdar 40, Baku st., Azerbaijan; e-mail: ibadullayeva.sayyar@ma1l.ru

${ }^{2}$ Department of Biology, Azerbaijan State Agrarian University, AZ200, Ataturk 450, Ganja st., Azerbaijan; e-mail: lala.qurbanova78@list.ru; aytan.w@mail.ru

${ }^{3}$ Department of Biology, Baku State University, AZ1148, Z.Khalilov 23, Baku st., Azerbaijan; e-mail: a.huseynova@mail.ru

${ }^{4}$ Department of Biology, Nakhchivan State University, AZ7012, Nakhchivan st., Azerbaijan; e-mail: hilal_1964@mail.ru

\begin{abstract}
The ethnopharmacological and nutritional significance of some wild vegetable plants belonging to the Polygonaceae Juss family widespread in the Azerbaijan flora and used in folk medicine has been described in the article. Although ethnic knowledge is passed down from generation to generation, some information is forgotten if it is not documented. Therefore, we set a goal to study the ethnopharmacological use of wild vegetables belonging to the Polygonaceae family widespread in the flora of Azerbaijan. The organs and developmental phases of plants used as medicine have been clarified, their importance as vegetables and therapeutic properties have been determined. Bioecological features of plants and their distribution areas have been found, reserves have been evaluated. Resource assessment has shown that the supply of the Rumex genus as a raw material will meet the full needs of local communities in vegetables and medicines. Ethnobotanical research was carried out by the methods of field ethnography, observation, survey, questionnaire, interview, etc. Interviews were conducted among human populations of all ages, with most people aged 65-85 providing the necessary information. It has been established that the representatives of the family are used as a food both in raw and cooked form. Their medicinal importance is different. Rumex species are mainly used as astringent, hemostatic, anti-tumor, wound healing substances, and in infectious diseases. Underground organs of Rheum species are used as astringent and hemostatic substances. Above-ground organs are used in kidney disease, gynecological diseases, lymphangitis, and furunculosis. Persicaria hydropiper is used in the treatment of hemorrhoids, gout, rheumatism, diseases of the endocrine system, Acogonon alpinum in diseases of the gastrointestinal tract and nervous system, and Polygonum species are mainly used as analgesics and anti-inflammatory drugs.
\end{abstract}

KEY WORDS Folk medicine; ethnopharmacology; resource assessment; Polygonaceae.

Received 11.05.2021; accepted 05.08.2021; published online 14.09.2021

\section{INTRODUCTION}

The healing properties of herbs have been known since ancient times. Our ancestors, who said, "Make medicine your food, and make food your medicine", used thousands of herbs, flowers, plant 
roots, vegetables, fruits and treated their ailments with herbal remedies. Research in this field has been conducted in Azerbaijan for many years and is being conducted now (Damirov et al., 1988; Karimov et al., 1996, Ibadullayeva et al., 20132021).

As a result of thousands of observations by the peoples of the world, the healing and other beneficial properties of hundreds of plants have been studied. In each province, healers and doctors treated people with phytotherapy. While 387 plant species were used in medieval Azerbaijani medicine (Alekperli, 2001) unfortunately, 252 species (69\%) of them are not included in the pharmacopeia in modern Azerbaijan medicine, and only 135 species are used as official medicinal plants. About 200 family, 1,100 genera, and 5,000 plant species of the Azerbaijan flora are currently used in folk medicine. However, there is no information in scientific sources about some of these plants. Recognition and use of such natural remedies by humans have stood the test of time and have continued to grow in importance in today's age of scientific and technological progress. The methods of modern folk medicine have been documented and published by us, information about the importance of some medicinal plants spread in our flora has been given (Ibadullayeva et al., 2010; 2012; 2015; 2017; Ibadllayeva, 2020; Munir et al., 2018; Saytar et al., 2021).

There are more than 800 species of 30 genera of the Polygonaceae Juss. family in the world, especially in the northern belt, of which 82 species of 11 genera are found in the flora of Azerbaijan (Flora of Azerb., 1952). Representatives of the family adapt to different environmental conditions. One of the characteristic features of the family is the more intensive flowering and fruiting processes.

Species of the Polygonaceae Juss family, especially their underground organs, are rich in tannins. Most of the species contain vitamins, some are food, dye, and ornamental plants. Some species are weeds. However, 14 species of the family belonging to different genera are widely used by local communities as both food and medicine. The purpose of this paper is to discuss the ethnopharmacological use of vegetable and food species. Thereby, the medicinal value of wild vegetables used by humans has also been revealed.

\section{MATERIAL AND METHODS}

In 2010-2021, the ethnobotanical study of plants was carried out using classical and modern methods. During the expeditions, 60 natural populations of Polygonaceae Juss. were selected, the phytocoenoses of plant areals, the principles of collection and use for medicinal purposes were studied, and resource assessments were conducted (Zayko et al., 2007). Plant life-forms were studied (Serebryakov, 1964) and developmental phases were clarified during collection for medicinal and food purposes. The research was carried out based on previously obtained ethnobotanical materials. This material was collected by the authors during surveys performed in different regions of Azerbaijan, especially with the older generation (Fig. 1).

Field research and expeditions were conducted in the Lesser Caucasus (Agstafa, Dashkasan, Goranboy, Goygol, Gadabay, Gazakh, Samukh, Tovuz, Ujar, Yevlakh), Talish (Hirkan, Lankaran), the Greater Caucasus (Zagatala, Shamakhi, Sheki) regions and the Nakhchivan Autonomous Republic (Sharur, Ordubad, and Shahbuz) of Azerbaijan. Ethnobiological views of both rural and urban populations were recorded (Fig. 2). The data collection was performed mainly in the form of personal conversations with representatives of the older generation who are well versed in folk medicine. Ethnobotanical research methods: field ethnography, observation, survey, questionnaire, interview, residual method, comparativehistorical method, component analysis, etc. (Martin, 1995; Guber, 2001). Technical recording equipment was often used in the observation process: a dictaphone, a film camera, and a video recorder.

To obtain information about local medicinal plants, first of all, local doctors engaged in phytotherapy were registered in the district administration. The rural community is constantly dependent on the traditional use of local plants for many diseases due to their low income and remoteness from health facilities. Considering these facts, the data collected in different regions were analyzed using the SPSS 9.00 version of the statistical program. The characteristics of plants, the number of responses given by families on the application of medicines prepared from them were 
estimated. The data collected were refined using percentages and ratios. The frequency of cases (FC) was calculated on the basis of reports presented by local communities for each plant species used. Use value: the relative importance of plant species was evaluated by calculating its use value as de- scribed by Phillips and Gentry [1993]. Use value for species $i \mathrm{UVi}=\sum \mathrm{Ui} / \mathrm{Ni}$, where the number of use report (s) cited by each informer for specific plant species $i$ is represented by Ui and total number of informers interviewed for specific plants pieces $i$ is represented by $\mathrm{Ni}$ (Table 1 ).

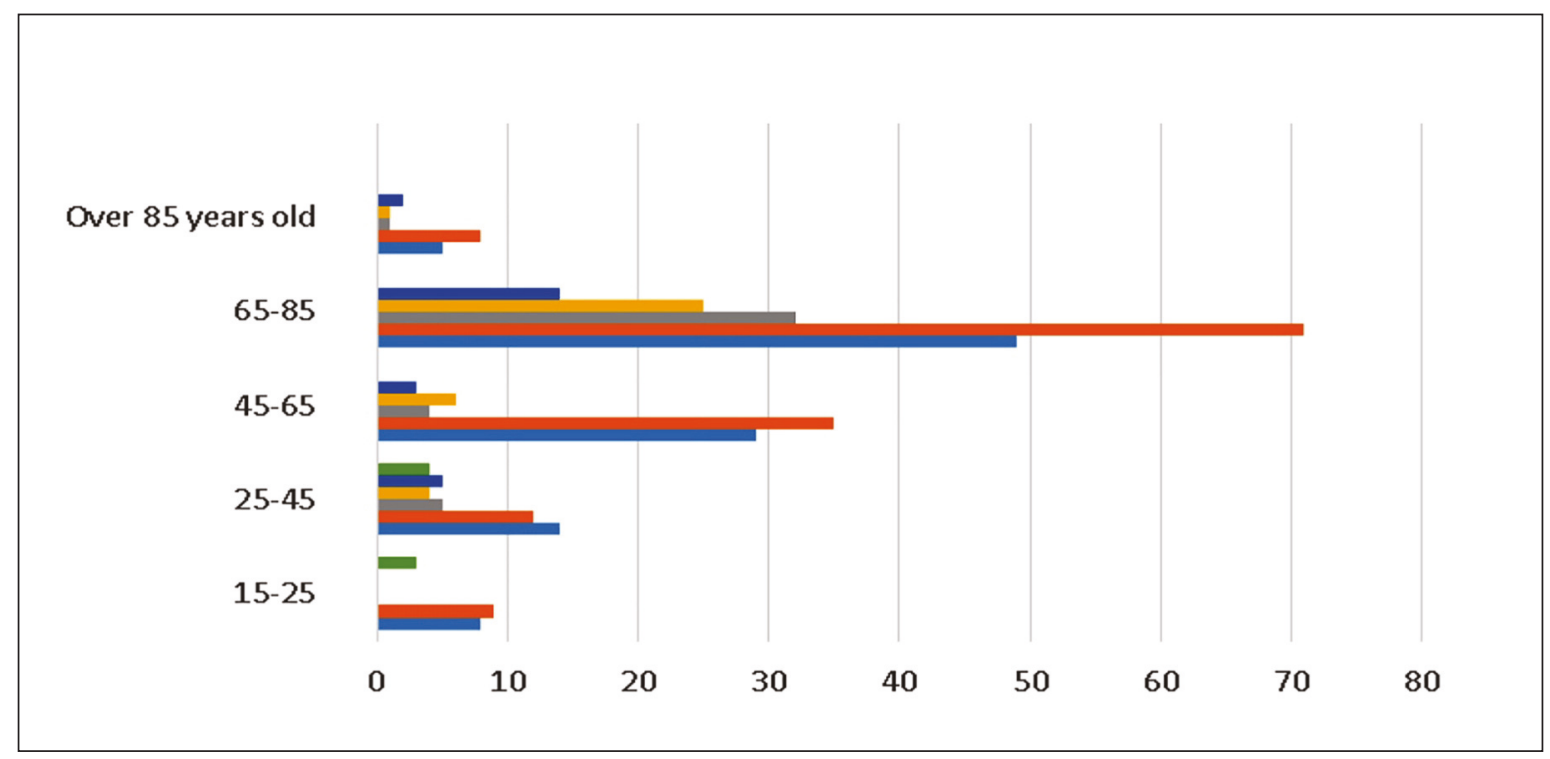

Figure 1. The number of human populations participating in the survey.

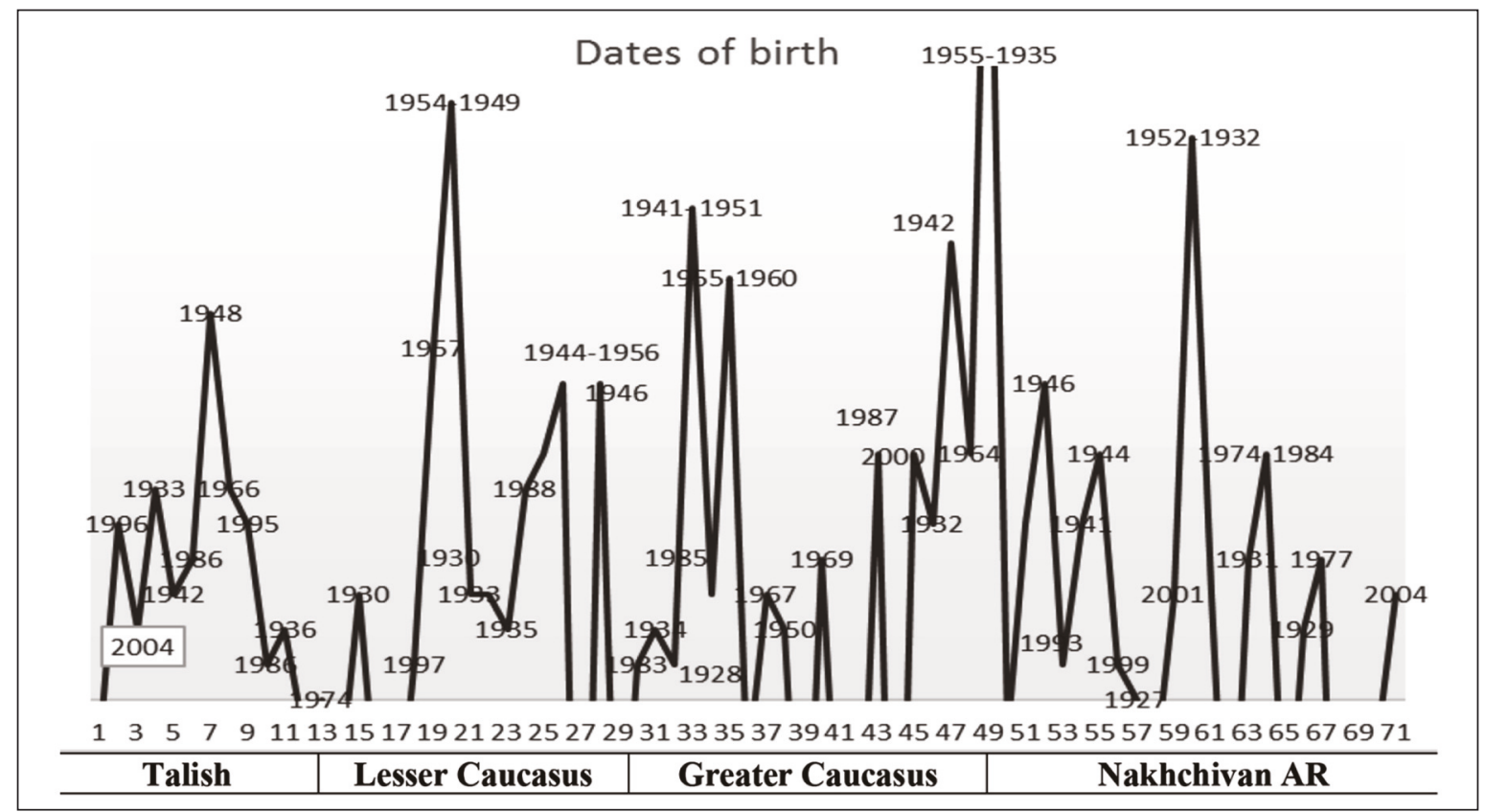

Figure 2. Age indicators of 75 rural communities participating in the interviews. 


\section{RESULTS}

At present, due to advanced and based on indepth scientific data use of medicinal plants, the basis is created for elimination diseases. Today, the ways to use herbs are versatile: herbal juices, raw salads, infusions, cooking, ointments, etc. The effect of their biologically active substances directly on the areas where the pathological process takes place, along with the treatment of the patient, also creates conditions for improving the defense system of the organism. It should be noted that herbal medicines never cause complications. During the expeditions and field excursions carried out by our group, conversations were held with the local population and the directions of use of species belonging to the Polygonaceae family in the regions were studied.

In the interviews, 20 people aged 15-25, 44 people aged 25-45, 77 people aged 45-65, 191 people aged 65-85, and 17 people over 85 were interviewed (Fig. 1). As it can be seen, the data on the use of plants as medicine and food were mostly obtained from the older generation. The use of medicinal plants and the population trust in this treatment method are no less important from an environmental point of view. Thus, a person who has experienced the importance of plants and their therapeutic effect will never be indifferent to such richness of nature and will protect them with all their heart. Thus, the areas of distribution of 14 species of the Polygonaceae family were carefully studied and the characteristics of vegetables, harvesting times, and ethnopharmacological features in folk medicine were determined (Table 1).

During the expedition and field excursions, the role of the above 14 species in the flora of Azerbaijan was determined and it was found that the family was represented in alpine and subalpine meadows by 6 (Oxyria digyna, Aconogonon alpinum, Polygonum alpestre, Rumex alpinus, Rheum turkestanicum and $R$. ribes) species, in forests by 1 (Rumex acetocella) species, and in swamp vegetation by 2 (Persicaria hydropiper and Polygonum monspelidense) species. The rest of the species were distributed in mountain-xerophyte vegetation. Of these species, Rheum turkestanicum and $R$. ribes were found only in the Nakhchivan Autonomous Republic, mainly in the highlands of the Shahbuz (Gishlag village Boz Gaya) and Sharur (Akhura, Havush heights) regions.

It should be noted that while the specificity of the natural conditions of the area is reflected in the systematic composition of its flora, the inhomogeneity of its ecological conditions allows determining the composition of life forms of phytocenoses, dominants in vegetation. During the research, taking into account the biomorphological features and their evolution, the ecological classification of the life forms of plants was studied, and the time of collection of the organ used for therapeutic purposes was also considered.

All species of the family used in ethnopharmacology are perennial herbs. We have noted that the Rumex species are widely used as a food plant and are distributed in Azerbaijan only in the biodiversity of LC, GC, and Nakhchivan Autonomous Republic, which is due to their mechanical growth. Representatives of the genera Rheum and Polygonum are mainly adapted to exochorous pollination by insects and propagate in this way. Therefore, their distribution area is limited.

Other species of the family are also distinguished by their beneficial properties and medicinal importance, but they are not used as vegetables. As a result of the research, it was found that some of the plants studied are widespread in the flora and can be used as a biological raw material base. However, some plants are in danger of extinction due to their unlimited gathering (Rheum ribes). The following table shows resource assessments of wild vegetables in the Polygonaceae family of the Azerbaijan flora used in ethnopharmacology (Table 2).

As seen in Table 2, there are still sufficient stocks of vegetable plants of medicinal importance in the two districts. They are widespread in the flora and can provide local communities. It should be noted that these plants are collected massively and sold in markets. Therefore, some species are endangered. Thus, the cultivation of the species used both as medicine and vegetables, in the regions, will prevent them from extinction. 


\begin{tabular}{|c|c|c|c|}
\hline $\begin{array}{l}\text { The Latin name } \\
\text { of the plant and } \\
\text { the number of FC }\end{array}$ & $\begin{array}{l}\text { Used organ } \\
\text { and months. } \\
\text { Spread regions }\end{array}$ & In ethnopharmacology & Use as a vegetable \\
\hline $\begin{array}{l}\text { Rheum ribes } \mathrm{L} \text {. } \\
\text { FC-15 }\end{array}$ & $\begin{array}{l}\text { Above-ground } \\
\text { parts, roots and } \\
\text { rhizomes; } \\
\text { V-VI; Nakh.AR }\end{array}$ & $\begin{array}{l}\text { The underground organs of the plant } \\
\text { have astringent and hemostatic proper- } \\
\text { ties. Above-ground organs are used in } \\
\text { kidney diseases, gynecological diseases, } \\
\text { lymphangitis, and furunculosis. Rheum } \\
\text { has an astringent effect when applied in } \\
\text { small doses, and a laxative effect at high } \\
\text { doses. It has also a strong sedative, anti- } \\
\text { inflammatory, antiseptic, choleretic, and } \\
\text { strengthening effect. }\end{array}$ & $\begin{array}{l}\text { Thick flower stalks are peeled and eaten } \\
\text { raw. Soup, porridge, omelet, compote, } \\
\text { pie, jam, marmalade, juice, etc. are } \\
\text { prepared from shoots. The shoots are } \\
\text { also dried and used in winter. }\end{array}$ \\
\hline $\begin{array}{l}\text { Rheum } \\
\text { turkestanicum } \\
\text { Janisch. } \\
\text { (= R. rupestre } \\
\text { Litv. ex Losinsk.) } \\
\text { FC-9 }\end{array}$ & $\begin{array}{l}\text { Above-ground } \\
\text { parts, roots; } \\
\text { IV-V; Nakh.AR }\end{array}$ & $\begin{array}{l}\text { The underground organs of the plant } \\
\text { have astringent and hemostatic proper- } \\
\text { ties. Above-ground organs are used in } \\
\text { kidney diseases, gynecological diseases, } \\
\text { lymphangitis, and furunculosis. }\end{array}$ & $\begin{array}{l}\text { Thick flower stalks are peeled and eaten } \\
\text { raw. Young shoots are collected by the } \\
\text { population in the spring for sale. Soup, } \\
\text { porridge, omelet, compote, pie, jam, } \\
\text { marmalade, juice, etc. are prepared } \\
\text { from shoots. The shoots are also dried } \\
\text { and used in winter. }\end{array}$ \\
\hline $\begin{array}{l}\text { Oxyria digyna } \\
\text { (L.) Hill } \\
\text { (= O.elatior R.Br. } \\
\text { ex Meissen.) } \\
\text { FC-6 }\end{array}$ & $\begin{array}{l}\text { Leaves and s } \\
\text { hoots; IV-VI; } \\
\text { GC, LC, } \\
\text { Nakh.AR }\end{array}$ & $\begin{array}{l}\text { It is used against inflammation of the } \\
\text { teeth and scurvy. }\end{array}$ & $\begin{array}{l}\text { The leaves and shoots are sour and } \\
\text { eaten fresh. The leaves have long been } \\
\text { used in the preparation of various } \\
\text { dishes. It improves the taste of dishes } \\
\text { such as dovgha, soup, bughlama, etc. } \\
\text { This plant is dried and stored for winter } \\
\text { by the local population. }\end{array}$ \\
\hline $\begin{array}{l}\text { Rumex } \\
\text { acetocella L. } \\
\text { FC-19 }\end{array}$ & $\begin{array}{l}\text { Above-ground } \\
\text { parts, VI-VIII; } \\
\text { GC, LC, } \\
\text { Nakh.AR }\end{array}$ & $\begin{array}{l}\text { The above-ground parts of the plant are } \\
\text { used in tumors, non-specific polyarthri- } \\
\text { tis, and as a wound-healing agent. Infu- } \\
\text { sions made from the leaves and shoots } \\
\text { are used in dental bleeding, urinary re- } \\
\text { tention, in the treatment of malignant tu- } \\
\text { mors, dysentery, hemorrhoids, } \\
\text { tuberculosis, etc. }\end{array}$ & $\begin{array}{l}\text { Salads are made from the leaves and } \\
\text { stems of the plant, pilaw and flat pie } \\
\text { with greens containing vitamins are } \\
\text { cooked. Young shoots and leaves are } \\
\text { eaten raw. It has a sour taste. It is dried } \\
\text { and added to dishes in winter. Different } \\
\text { salads are prepared from fresh leaves. } \\
\text { Young shoots are salted and stored for } \\
\text { winter use. }\end{array}$ \\
\hline $\begin{array}{l}\text { Rumex } \\
\text { acetosa L. } \\
\text { FC-20 }\end{array}$ & $\begin{array}{l}\text { Above-ground } \\
\text { parts, V-VI; GC, } \\
\text { LC, Nakh.AR }\end{array}$ & $\begin{array}{l}\text { It is used in non-specific polyarthritis, } \\
\text { infectious diseases, wound healing. The } \\
\text { choleretic juice of the plant is used also } \\
\text { against fever, scurvy, itching, rheuma- } \\
\text { tism. Infusions are used in internal blee- } \\
\text { ding, skin diseases as a bandage, in the } \\
\text { treatment of tumors, and urinary reten- } \\
\text { tion. The fruit infusion is used as a re- } \\
\text { medy. }\end{array}$ & $\begin{array}{l}\text { The locals gather these plants in May- } \\
\text { June before flowering and braid them } \\
\text { like hair, dry and prepare them for the } \\
\text { winter. The leaves are used as a vegeta- } \\
\text { ble. Various dishes are prepared from } \\
\text { the dried plant in winter. }\end{array}$ \\
\hline $\begin{array}{l}\text { Rumex crispus } \mathrm{L} . \\
\text { FC-26 }\end{array}$ & $\begin{array}{l}\text { Roots and above- } \\
\text { ground parts; } \\
\text { V-VI; }\end{array}$ & $\begin{array}{l}\text { An ointment made from the roots and } \\
\text { leaves is used in tuberculosis, cancer, } \\
\text { strengthening the gums, and as an anti- } \\
\text { alcoholic agent. It is used as a laxative, } \\
\text { astringent, wound healing, diaphoretic, } \\
\text { and antipyretic agent. }\end{array}$ & $\begin{array}{l}\text { Dried parts of the plant are cooked and } \\
\text { used. In winter, it is used for cooking } \\
\text { pilaw or fried with oil and onions. The } \\
\text { dried parts are chopped and added to } \\
\text { various dishes. Freshly picked leaves } \\
\text { and stems of the plant are used in salads } \\
\text { and pies. }\end{array}$ \\
\hline
\end{tabular}




\begin{tabular}{|c|c|c|c|}
\hline $\begin{array}{l}\text { Rumex patientia } \\
\text { L. FC-17 }\end{array}$ & $\begin{array}{l}\text { Roots and above- } \\
\text { ground parts; V- } \\
\text { VI; GC, LC, T., } \\
\text { Nakh.AR }\end{array}$ & $\begin{array}{l}\text { Infusion of roots and leaves is used as a } \\
\text { laxative, astringent, wound healing, } \\
\text { diaphoretic, and antipyretic agent. }\end{array}$ & $\begin{array}{l}\text { The dried plant is cooked and used. The } \\
\text { dried parts are chopped to give the food } \\
\text { a sour taste as a food additive. Freshly } \\
\text { picked leaves and stems of the plant are } \\
\text { used in salads and pies. }\end{array}$ \\
\hline $\begin{array}{l}\text { Rumex alpinus L. } \\
\text { FC-9 }\end{array}$ & $\begin{array}{l}\text { Roots and above- } \\
\text { ground parts; V- } \\
\text { VI; GC, LC, } \\
\text { Nakh.AR }\end{array}$ & $\begin{array}{l}\text { The extract from the root treats diarrhea, } \\
\text { benign and malignant tumors. In folk } \\
\text { medicine, its infusion and extract are } \\
\text { used as astringent, it strengthens the } \\
\text { gums, and is used in colds. }\end{array}$ & $\begin{array}{l}\text { The leaves are used as food, for prepa- } \\
\text { ring salad and cakes. The above-ground } \\
\text { parts of the plant are dried and used in } \\
\text { winter. }\end{array}$ \\
\hline $\begin{array}{l}\text { Rumex euxinus } \\
\text { Klok. FC-11 }\end{array}$ & $\begin{array}{l}\text { Leaves; V-VII; } \\
\text { GC, LC, Nakh.AR }\end{array}$ & $\begin{array}{l}\text { It is used in the treatment of gastrointe- } \\
\text { stinal diseases. }\end{array}$ & $\begin{array}{l}\text { The leaves are used as food. Dried and } \\
\text { braided leaves are cooked and fried } \\
\text { with oil and onion, added to various } \\
\text { dishes, including pilaw. }\end{array}$ \\
\hline $\begin{array}{l}\text { Rumex scutatus } \\
\text { L. FC-19 }\end{array}$ & $\begin{array}{l}\text { Leaves; V-VI; } \\
\text { GC, LC, T, } \\
\text { Nakh.AR }\end{array}$ & $\begin{array}{l}\text { Dishes made from this plant are not only } \\
\text { tasty food but also have medicinal value. } \\
\text { It helps normalize the gastrointestinal } \\
\text { tract. When cooked in water and rice } \\
\text { broth it is a powerful remedy for } \\
\text { diarrhea. }\end{array}$ & $\begin{array}{l}\text { The locals collect this plant before the } \\
\text { flowering and weave it like hair, dry and } \\
\text { store it for winter. Various dishes are } \\
\text { prepared from the dried plant in winter: } \\
\text { pilaw, umaj, gindi, which is prepared } \\
\text { with milk, dovgha, gutab, soup, etc. The } \\
\text { leaves are edible. }\end{array}$ \\
\hline $\begin{array}{l}\text { Polygonum } \\
\text { monspelidense } \\
\text { Thieb.ex Pers } \\
\text { (= Polygonum } \\
\text { aviculare L.) } \\
\text { FC-26 }\end{array}$ & $\begin{array}{l}\text { Above-ground } \\
\text { parts; IV-V; GC, } \\
\text { LC, T, Nakh.AR }\end{array}$ & $\begin{array}{l}\text { Herbal infusions and extracts are used in } \\
\text { the treatment of gastrointestinal diseases, } \\
\text { as a painkiller, and an anti-inflammatory } \\
\text { agent. Its leaves are used to treat dislo- } \\
\text { cations, fractures, and furuncles. Prepa- } \\
\text { rations made from it are used against } \\
\text { fever, tumors, and tuberculosis. In scien- } \\
\text { tific medicine, dried grass is used as he- } \\
\text { mostatic in internal bleeding, and the } \\
\text { extract is used as a diuretic. }\end{array}$ & $\begin{array}{l}\text { The above-ground parts are collected } \\
\text { until flowering. The plant is used raw } \\
\text { and cooked. Dovgha, bughlama, pilaw, } \\
\text { pie, etc. are prepared. Salads are prepa- } \\
\text { red from the fresh plant. Puree is } \\
\text { cooked with urtica. Its rice-cooked } \\
\text { pilaw is very tasty with garlic yogurt. } \\
\text { It is supplied for the winter and used to } \\
\text { make umac and sabzi (fried with meat). } \\
\text { Its flour obtained by drying and } \\
\text { grinding is used to make porridge. }\end{array}$ \\
\hline $\begin{array}{l}\text { Polygonum } \\
\text { alpestre C.A. } \\
\text { Mey. } \\
\text { FC-11 }\end{array}$ & $\begin{array}{l}\text { Above-ground } \\
\text { parts; IV-V; GC, } \\
\text { LC, T, Nakh.AR }\end{array}$ & $\begin{array}{l}\text { Infusions and extracts prepared from } \\
\text { above-ground parts are used for medici- } \\
\text { nal purposes in the treatment of gastroin- } \\
\text { testinal diseases, as a painkiller and } \\
\text { anti-inflammatory agent. }\end{array}$ & $\begin{array}{l}\text { The aboveground parts are collected } \\
\text { until flowering. The plant is used raw } \\
\text { and cooked. Dovgha, bughlama, pilaw, } \\
\text { pie, etc. are prepared. Salads are prepa- } \\
\text { red from the fresh plant. Its rice-cooked } \\
\text { pilaw is very tasty with garlic yogurt. It } \\
\text { is dried and supplied for winter. It is } \\
\text { used to make umac and sabzi (fried with } \\
\text { meat). Its flour obtained by drying and } \\
\text { grinding is used to make porridge. The } \\
\text { leaves are used as food when raw. }\end{array}$ \\
\hline $\begin{array}{l}\text { Aconogonon } \\
\text { alpinum (All.) } \\
\text { Schur FC-7 }\end{array}$ & $\begin{array}{l}\text { Roots, rhizomes, } \\
\text { young shoots; V- } \\
\text { VI; BP, GC, LC, } \\
\text { Nakh.AR }\end{array}$ & $\begin{array}{l}\text { Infusion and extract made from roots } \\
\text { and rhizomes are used in the treatment } \\
\text { of the diseases of the gastrointestinal } \\
\text { tract and the nervous system. It is used } \\
\text { as tonic and astringent agent. When } \\
\text { chopped, it is placed on the tumors. The } \\
\text { extract from above-ground parts is used } \\
\text { against tuberculosis, cough, diarrhea } \\
\text { and scurvy. }\end{array}$ & $\begin{array}{l}\text { Young shoots have a sour taste. They } \\
\text { are peeled and eaten fresh. Shoots are } \\
\text { used raw and cooked for preparing } \\
\text { salads, pies, gutab, etc. It is also added } \\
\text { to meat dishes. Young stems are used } \\
\text { after peeling and salting. }\end{array}$ \\
\hline
\end{tabular}




\begin{tabular}{|lll|}
\hline $\begin{array}{l}\text { Persicaria } \\
\text { hydropiper }\end{array}$ & Leaves; V-VII; & In folk medicine, it is prescribed in the The dried leaves of the plant are a \\
(L.) Spach & & $\begin{array}{l}\text { form of infusions and decoctions for he- culinary spice. A pie is baked } \\
\text { morrhoids, gout, rheumatism, diseases from young shoots. } \\
\text { FC-12 }\end{array}$
\end{tabular}

Table 1. Ethnopharmacological use of wild vegetables of the Polygonaceae Juss. family in the Azerbaijan flora. GC: Botanical-geographical regions of the Greater Caucasus (Sheki, Ismayilli, Shamakhi); LC: Botanical-geographical regions of the Lesser Caucasus (center, south, and north-east of LC); Nakh.AR: Nakhchivan Autonomous Republic (Nakhchivan mountain, Nakhchivan plain, Nakhchivan High mountain villages); BP: Bozgir plateau; T: Talish.

\begin{tabular}{|c|c|c|c|c|}
\hline Species & Spread area (ha) & 10 kv2 number & $\begin{array}{c}\text { Biological reserve } \\
\text { (ton) }\end{array}$ & Annual supply (ton) \\
\hline Rumex euxinus & 675 & $19+0.09$ & $1051.2+51.86$ & $525.1+0.88$ \\
\hline Rumex acetosella & 714 & $15+0.05$ & $4940.0+220.6$ & $2494.0+2.26$ \\
\hline Rumex acetosa & 1100 & $25+0.09$ & $9245+473.32$ & $1824.5+4.72$ \\
\hline Rumex scutatus & 1171 & $28+0.14$ & $3301+139.67$ & $1530.1+1.37$ \\
\hline Rumex patientia & 4803 & $15.6 \pm 1.25$ & $2940.8 \pm 238.0$ & $1470.4 \pm 119.0$ \\
\hline Rumex alpinus & 875 & $9.61 \pm 0.79$ & $1736.25 \pm 149.4$ & $868.12+74.7 .0$ \\
\hline Rumex crispus & 4981 & $19.45 \pm 1.60$ & $3170.64 \pm 248.4$ & $1585.32 \pm 124.2$ \\
\hline Oxyria digyna & 428 & $8.67 \pm 0.62$ & $1823.28 \pm 156.8$ & $911.64 \pm 78.4$ \\
\hline Aconogonon alpinum & 105 & $9+0.05$ & $71.35+0.30$ & $37.15+0.03$ \\
\hline $\begin{array}{l}\text { Polygonum } \\
\text { monspelidense }\end{array}$ & 235 & $16+0.09$ & $3015+204.6$ & $1501.5+2.61$ \\
\hline Polygonum alpestre & 570 & $14+0.07$ & $3814+214.68$ & $1812.4+1.87$ \\
\hline Persicaria hydropiper & 765 & $21.77 \pm 1.80$ & $3169.64 \pm 240.28$ & $1584.8+120.14$ \\
\hline Rheum ribes & 178 & $7+0.03$ & $1367+79.26$ & $786.7+0.96$ \\
\hline Rheum turkestanicum & 80 & $15+0.08$ & $360+21.42$ & $170+0.14$ \\
\hline
\end{tabular}

Table 2. Resource assessments of wild vegetables in the Polygonaceae family of the Azerbaijan flora (Shahbuz and Sharur districts of the Nakhchivan AR, Goygol, and lowland Garabagh regions of the Lesser Caucasus) used in ethnopharmacology.

\section{CONCLUSIONS}

Ethnobotanical analysis revealed that information on the use of plants was obtained mainly from women aged $65-85$ years.

The underground organs of the Rheum species are astringent and hemostatic, the above-ground organs are used in kidney diseases, gynecological diseases, lymphangitis and furunculosis; Persicaria hydropiper in hemorrhoids, gout, rheumatism, endocrine system diseases; Acogonon alpinum in diseases of the gastrointestinal tract and the nervous system; Root extracts of Rumex species are used for the treatment of diarrhea, benign and malignant tumors. Polygonum species are mainly used as painkillers and anti-inflammatory agents. 
The analysis of the Resource assessments showed that species of the Rumex genus have the following annual supply reserves: $R$. crispus $1585.32, R$. patientia $1470.4, R$. asetosa $1824.5, R$. alpinus 868.12, $R$. acetosella $2494 R$. euxinus 1530.1 tons. Besides, the species of the Polygonum genus can supply the following annual raw material: Polygonum monspelidense 1501.5, P. alpestre 1812.8; Persicaria hydropiper 1584.8; Oxyria digyna 911.64; Rheum ribes 786.7, Rh. turkestanicum 36; Aconogonon alpinum 170 tons.

\section{REFERENCES}

Alekperli F.U., 2001. A thousand and one secrets of the East. Vol. I. Tural Publishing House, Baku, 505 pp. (in Russian).

Damirov I.A., Prilipko L.I., Shukurov D.Z. \& Kerimov Yu.B., 1988. Medicinal plants of Azerbaijan. Baku, 319 pp. (in Russian).

Kerimov Y.B., Islamova N.A., Khalilov D.S., Jafarova R.E., Suleymanov T.A., Isayev D.I. \& Aghayev E.M., 1996. Prospects for the use of medicinal plant raw materials and the production of phytopreparations in Azerbaijan. Baku, 84 pp. (in Russian).

Ibadullayeva S.J., Jafarli I., Mohammad Z. \& Asbghian Namin S.S., 2017. Folk medicine (Ethnobotany in Azerbaijan Region), IIR, Tehran, 288 pp.

Ibadullayeva S. \& Shahmuradova M., 2015. Ethnobotanical researches in Azerbaijan (Goygol region), EIMTEHSIL, Baku, 222 pp.

Ibadullayeva S. \& Alakbarov R., 2013. Medicinal plants (Ethnobotany and Phytotherapy). Medicinal plants (Ethnobotany and Phytotherapy). Baku, Science, 331 pp. (in Azerbaijani).

Ibadullayeva S.J., Shahmuradova M., Gahramanova M. \& Aliyeva Sh.G., 2012. Use of wild plants at dermatosis (skin diseases): Ethnobotany. Journal of Applied Pharmaceutical Science, 2: 64-67. https://doi.org/10.7324/JAPS.2012.2809

Ibadullayeva S., Mamedova S.E., Sultanova Z.R., Movsumova N.V. \& Jafarli I.A., 2010. Medicinal plants of Azerbaijan flora used in the treatment of certain diseases. International Journal of Pharmacy and Pharmacology, 4: 545-548.

Phillips O. \& Gentry A.H., 1993. The useful plants of Tambopata Peru: I. Statistical hypotheses tests with a new quantitative technique. Economic Botany, 47: $15-32$.

Sayyara J. Ibadullayeva \& Irada M. Huseynova, 2021. An Overview of the Plant Diversity of Azerbaijan. Biodiversity, Conservation and Sustainability in Asia. Vol. 1: Prospects and Challenges in West Asia and Caucasus. Editors Münir Öztürk, Volkan Altay, Recep Efe, pp. 431-478

Sayyara J. Ibadullayeva., 2020. Ethnobotany of local use of medicinal plants in Azerbaijan Republic. Journal of Medicine and Biology. Research Article, 2: 72-84 Sytar O., Brestic M., Hajihashemi S., Skalicky M., Kubeš J., Lamilla-Tamayo L., Ibrahimova U., Ibadullayeva, S. \& Landi M., 2021. COVID-19 Prophylaxis Efforts Based on Natural Antiviral Plant Extracts and Their Compounds. Molecules, 26: 727. https://doi.org/10.3390/molecules 26030727

Serebryakov I.G., 1964. The life form of higher plants and their study. Field geobotany. Nauka. T.Z., pp. 146-202.

Guber R. La, 2001. Etnografia. Metodo, campo y reflexividad. Norma, Bogota.

Martin G.J., 1995. Ethnobotany: A Methods Manual. Chapman and Hall, London.

Munir Ozturk, Volkan Altay, Sayyar Ibadullayeva, Ernaz Altundağ, Behnaz Aslanipour, Tuba Mert Günenç (2018. Herbals in Iğdır (Turkey), Nakhchivan (Azerbaijan), and Tabriz (Iran). Herbs and Human Health, Ethnobotany and Physiology, 1: 197-267.

Flora of Azerbaijan, 1952. Vol. III. Baku, in Russian.

Zayko L.N., Pimenova M.E. \& Aslikov V. Yu., 2007. Review of the method and results of the study of medicinal plants of Russia (According to the materials of VILAR). Proceedings of the International Scientific and Practical Conference. Modern problems of phytodesign. Belgorod, pp. 148-157 (in Russian). 